\title{
EL AMOR LIBRE Y LAS RELACIONES SENTIMENTALES EN EL ANARQUISMO ESPAÑOL (1930-1939)
}

\author{
FREE LOVE AND SENTIMENTAL RELATIONSHIPS \\ IN SPANISH ANARCHISM (1930-1939)
}

\author{
Alejandro Lora Medina*
}

Universidad de Sevilla (España)

\begin{abstract}
RESUMEN: Este artículo pretende analizar la percepción y la representación del amor libre en el anarquismo español de los años treinta, principalmente a través de la prensa, contraponiendo el discurso teórico defendido por sus propagandistas con las experiencias que tales prácticas generaron en una sociedad muy apegada a la moral tradicional. Su defensa se inserta dentro del cambio ético propugnado por la ideología anarquista para una transformación integral de la persona, en un periodo en que la nueva legislación republicana iba a generar la situación adecuada para implementar dichas ideas. El amor libre anarquista tomaría la forma de uniones libres monógamas, pluralismo amoroso o, incluso, el matrimonio civil como opciones posibles de unos militantes, a los que únicamente se les pedía que se comportaran activamente conforme a su ideario.
\end{abstract}

PALABRAS CLAVE: España, anarquismo, amor libre, Segunda República, Guerra Civil.

ABSTRACT: This article aims to analyze the perception and representation of free love in the Spanish anarchism of the thirties, fundamentally through the press, contrasting the theoretical discourse defended by its propagandists with the experiences that these practices generated in a society very attached to traditional morality. Its defense is inserted within the ethical change supported by the anarchist ideology for an integral transformation of the person, in a period then the new republican legislation was going to generate the right situation to implement those ideas. Free anarchist love would take the form of monogamous free unions, loving pluralism or even civil marriage as possible options of some militants, who were only asked to behave actively according to their ideology.

KEYWORDS: Spain, anarchism, free love, Second Republic, Spanish Civil War.

* Correspondencia a: Alejandro Lora Medina. Universidad de Sevilla. Departamento de Historia Contemporánea. María de Padilla s/n. Sevilla 41004 - alora@us.es - https://orcid.org/0000-0002-7314-8327

Cómo citar: Lora Medina, Alejandro (2019). «El amor libre y las relaciones sentimentales en el anarquismo español (19301939)»; Historia Contemporánea, 60, 581-617. (https://doi.org/10.1387/hc.19430).

Recibido: 13 marzo, 2018; aceptado: 10 julio, 2018.

ISSN 1130-2402 - eISSN 2340-0277 / (C) 2019 UPV/EHU 


\section{Introducción}

El amor es uno de los temas por antonomasia en las relaciones humanas y su evolución a lo largo de la historia está intrínsecamente relacionada con la cultura dominante y la moralidad vigente. El amor romántico, concepto actualmente imperante, es consecuencia directa de una construcción cultural nacida a finales del siglo XVIII como parte del cambio de paradigma experimentado en las relaciones sentimentales en la naciente sociedad industrial con el éxito del liberalismo y el individualismo. Dicho concepto se inserta en una población que introduce en las relaciones matrimoniales, junto a los condicionantes económicos y sociales habituales, el sentimiento amoroso como eje de la pareja moderna. Al tratarse de un campo abonado al debate y la interpretación, no faltan los estudios que abordan su análisis desde una triple concepción: el amor como pasión, como sentimiento y como estado romántico. Su complejidad se acrecienta al entroncar con el mundo de lo emotivo porque los sentimientos, a pesar de ser construcciones abstractas que no permanecen fijas a lo largo de la historia, pueden ser analizadas. Es ahí donde adquiere importancia la representación como mecanismo para dilucidar la percepción del objeto de estudio, pero no sólo de los individuos o el grupo en el que se incluyen, sino de ellos mismos y de su sociedad. Esto se debe, como señalara Roger Chartier, a la importancia de las imágenes proyectadas socialmente por una colectividad y cómo esta capacidad performativa de las mismas conseguía evocar y crear en el individuo la representación de una idea. Esta se convertía en el paso previo para su extensión y desarrollo práctico en común. Su importancia estaba intrínsecamente relacionada con otras cuestiones relacionadas con el amor libre como serían: la familia, la maternidad/paternidad, el divorcio o el aborto ${ }^{1}$.

De este modo, este trabajo pretende mostrar una visión general de la concepción ácrata del amor y de sus prácticas en la vida cotidiana de los militantes libertarios durante los años treinta. La noción de amor utilizada, siguiendo a Pierre Bourdieu en su concepción del habitus - entendido como pensamiento interiorizado y reproducido de generación en generación de forma inconsciente-, nos lleva a señalar la existencia de una «lucha» de poder entre la visión anarquista y la entonces vigente. De este modo, los escritos publicados en la prensa ácrata per-

\footnotetext{
${ }^{1}$ Chartier, 2007, p. 70; Rodríguez Salazar, 2012, pp. 155-180.
} 
siguen la sustitución del habitus burgués dominante en las relaciones sentimentales y sexuales por el suyo propio - el del amor libre-, que pasaría de ser percibido como estructura estructurada a estructura estructurante. Se trata de generar un conjunto de prácticas que sean interiorizadas y divulgadas por una militancia, educada en otros patrones de comportamiento totalmente opuestos. La pertenencia del discurso amoroso al ámbito de lo cotidiano y lo sentimental dificulta su definición según parámetros académicos, de ahí que su abordaje desde la sociología y la antropología permita acercarse con mayor profundidad, no sólo a la concepción sentimental, sino también al conjunto de prácticas que lo definen. El amor, como ha analizado John Goode, tiene hondas implicaciones sociales tanto a nivel macro como micro, de ahí que nuestro interés se centre tanto en el carácter perturbador que supone el amor libre en el orden social burgués, como de la idiosincrasia de una manera de amar rupturista y cuyo carácter revolucionario se convirtió en un elemento identitario del anarquismo español ${ }^{2}$.

Los trabajos de Richard Cleminson y Mary Nash ofrecen una aproximación general al tema de las relaciones amorosas en el anarquismo español desde principios de siglo. Aunque sus estudios son centrales para el conocimiento del tema, estos resultan insuficientes para la etapa de la Segunda República y la Guerra Civil. El escaso tratamiento historiográfico que han recibido hasta tiempos recientes las relaciones sentimentales nos lleva a abordar su análisis principalmente a través de la prensa y desde una doble perspectiva que combina su vivencia práctica con su concepción filosófica. La elección de este tipo de fuentes se debe a que son las que mejor permiten analizar los habitus y las representaciones que el movimiento ácrata generó acerca de la esfera teóricopráctica del amor libre. Debido a que, al tratarse de noticias y artículos desde una evidente óptica propagandística, estaban libres de un discernimiento más pausado y consciente de lo narrado (como pudiera suceder en memorias o autobiografías), permitiéndonos conocer de forma directa todo un universo mental que de otro modo habría sido casi imposible tan siquiera de vislumbrar.

2 Sellés, 2013, pp. 107-131; Choza, 2011; Bourdieu, 2007; Bourdieu, 2010; Rodríguez Salazar, 2012, pp. 155-180; Álvarez Lacruz, 2006; Stone, 1990; Avilés Farré, 1988-1989, p. 69; Corona Berkin \& Rodríguez Morales, 2000, pp. 49-70; Goode, 1959, pp. 38-47. 


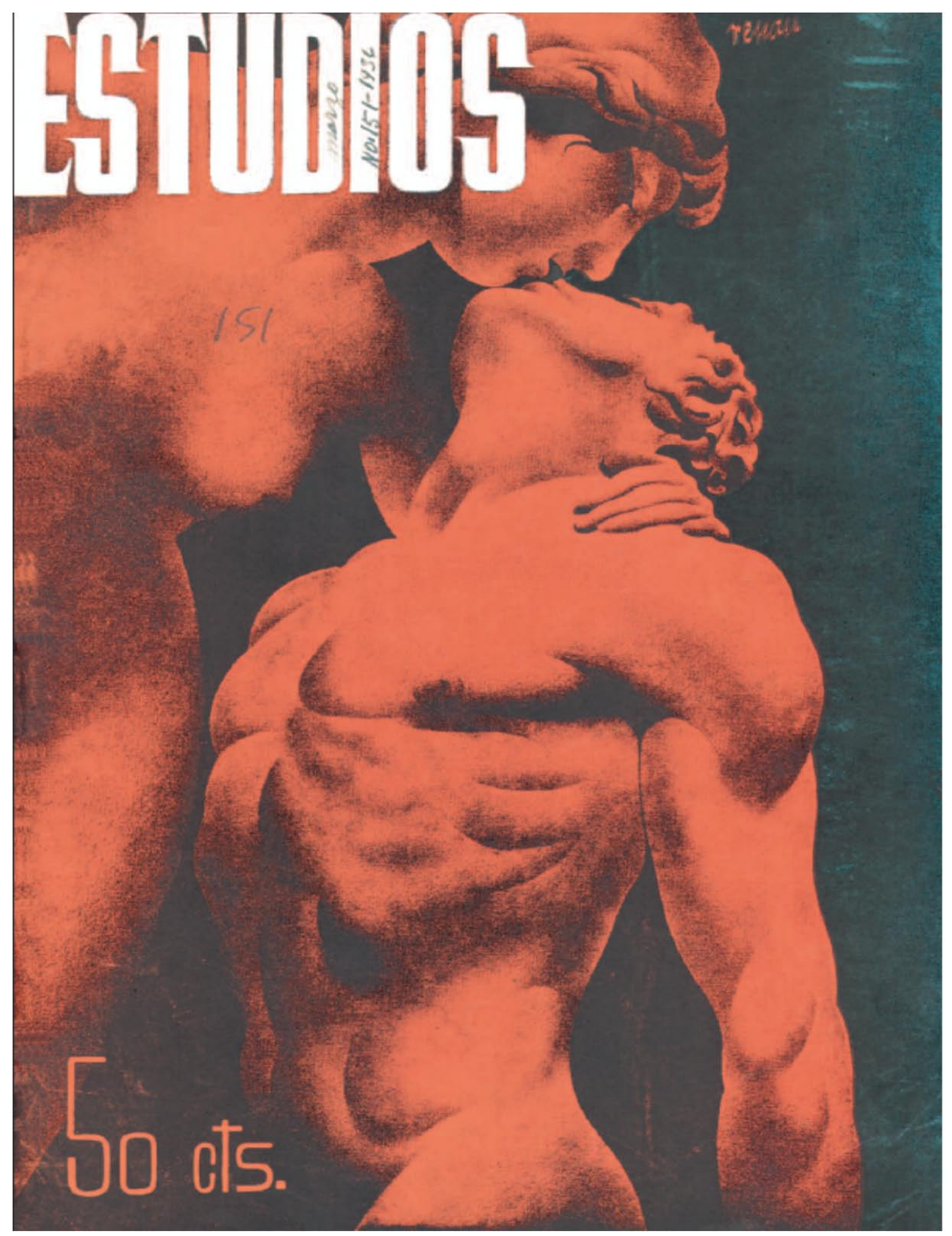

Figura 1

Estudios, 151, marzo de 1936, portada. 
Para esta labor resultan especialmente relevantes «La Revista Blanca» (1930-1936) y «Estudios. Revista Ecléctica» $(1930-1937)^{3}$, que destacan sobre la ingente producción editorial ácrata tanto por su difusión de carácter nacional, como por la riqueza y relevancia de sus páginas en lo concerniente a esta temática. La novedad de este estudio reside en ofrecer un compendio entre teoría y práctica a través del pensamiento de un variado número de militantes, unos más conocidos que otros, para configurar así un panorama general, diverso y lo más completo. Al mismo tiempo se pretende abordar su desarrollo aunque en un corto periodo de tiempo, pero tan rico y complejo por todos los cambios políticos y sociales que acontecieron en los años treinta y que influyeron directamente en el devenir del amor libre y su puesta en práctica.

\section{El amor libre a debate: un recorrido por los años treinta}

El estudio de las relaciones sentimentales en el anarquismo español, configuradas bajo el término genérico de «amor libre», resulta de difícil abordaje desde una perspectiva generalista, no sólo por el carácter abiertamente heterodoxo de su ideología, sino por la diversidad y contradicción de muchos de los alegatos emitidos. En toda esta casuística sobresalen tres elementos que destacan particularmente sobre el resto -igualdad, individualismo y sentimentalismo-, como elementos centrales de un concepto que evidenció la enorme separación entre teoría y praxis. Lejos de circunscribirse al ámbito historiográfico actual, fue un debate especialmente pródigo en los círculos anarquistas, muy conscientes de esta indefinición que impedía cierta homogeneización para abogar por su práctica concreta. Antonia Maymón, maestra racionalista madrileña, señala en la revista Estudios que, al no existir una única forma de entender el sentimiento amoroso, éste podía malinterpretarse y hacerse apología de algo que no era en sí lo que se debería entender a su juicio por amor libre ${ }^{4}$.

Esta indefinición formal permitía que la prensa conservadora y grupos afines, que se sentían atacados por la retórica y el proceder ácrata en la esfera pública, utilizaran los medios a su alcance para criticar y conde-

${ }^{3}$ Sobre la relevancia de las fuentes consultadas: Corti, 1987; López Campillo, 1995, pp. 237-242; Navarro Navarro, 1997; Díez, 2001.

${ }^{4}$ Nash, 1981, pp. 48, 49; Andrés Granel, 2008, p. 74; Díez, 2007, p. 256; Díez, 2002, pp. 101, 102; Estudios, 92, abril de 1931, p. 34. 
nar unas prácticas que atentaban contra el orden familiar burgués y patriarcal. No sólo se iba a difundir la imagen del amor libre como la más abyecta representación de la concupiscencia desenfrenada, sino que fruto de esas prácticas nacería una sociedad sexuada, enferma, promiscua y moralmente degenerada. Los propios anarquistas, conscientes de esta propaganda, intentaron contrarrestarla acudiendo a su prensa para explicar qué encerraba, en líneas generales, dicho término5:

«El vulgo, cuando se habla de amor y libertad, de amor libre, enseguida, rápidamente interpreta: escándalo, libertinaje, prostitución... Sin embargo; si tomamos por separado estos dos vocablos, no hay quien oponga el menor reparo a desenvolver sus actividades en libertad máxima, ni quien haya dejado de desear el amar sin obstáculos de ninguna índole» ${ }^{6}$.

Para los anarquistas, el amor es un elemento consustancial al ser humano y está ligado a los dones que la naturaleza le ha brindado a lo largo de su existencia. Esta visión naturalista se extiende a la idea del amor como una ley natural, anterior a religiones y leyes, que debe rescatarse del olvido como una práctica más que conducirá a la tan ansiada revolución. El amor libre es la única vía aceptable y sin condicionantes externos que tienen hombres y mujeres de unirse sentimentalmente ya que, al eliminarse de la ecuación amorosa a la Iglesia y al Estado, sólo prevale la aceptación mutua de la pareja como fermento único de la unión. Es lo que Higinio Noja - destacado propagandista, novelista y maestro racionalista onubense - denomina «afinidad electiva ${ }^{7}$, que supone el ensalzamiento de la libertad individual por encima del carácter mercantilista, reglado y religioso que subyacía desde tiempos pretéritos en el matrimonio tradicional. Amparo Poch y Gascón, una de las fundadoras de Mujeres Libres y directora del Casal de la Dona Treballadora durante la Guerra Civil, señala que las relaciones amorosas debían construirse por etapas y siempre a voluntad de los enamorados. Son uniones marcadas especialmente por su temporalidad y disolubilidad, ya que el amor romántico se entiende como un sentimiento que, del mismo modo

$5 A B C, 05-02-1936$, p. 3; $A B C$, n. ${ }^{\circ}$ extraordinario, enero de 1934, p. 35; Álvarez Junco, 1991, p. 294.

6 La Verdad, 9, agosto de 1932, p. 4.

7 NOJA RUIZ, H., «La atracción sexual», Estudios, n. ${ }^{\circ}$ 77, enero 1930, Valencia, p. 25. 
que nace, se acaba. Entonces, tanto hombres como mujeres eran igual de libres para romper la unión sin tener que recurrir a ninguna institución que avalase dicha separación ${ }^{8}$.

Esta igualdad teórica de los sexos, tan alabada en la prensa ácrata, se encontraba con la realidad de una sociedad cuyo avance en derechos sociales era más lento que la palabra escrita. Para José Villaverde, secretario del Comité Regional de la CNT gallega y director de Solidaridad Obrera durante la Segunda República, la defensa del amor libre estaba indefectiblemente ligada al derecho de la mujer a disponer de su cuerpo y sentimientos como quisiera. Otros anarquistas como el médico catalán Javier Serrano, que solía escribir bajo los seudónimos de Dr. Klug o Dr. Fantasma, o Higinio Noja consideraban que había todavía demasiados libertarios que no aceptaban que su compañera tuviera los mismos derechos que ellos, y que era necesaria una verdadera revolución de las conciencias. Mientras, el anarquista portugués Leandro Carré, más conocido por sus artículos bajo el nombre de Fausto Brand, en una sociedad que imposibilitaba la libertad económica del individuo era irreal querer implantar un régimen sentimental de amor libre?.

Estas evidencias denotan, como señala Mariano Gallardo, que el comportamiento de muchos libertarios no estaba a la altura de las ideas defendidas por un movimiento tan exigente moral y éticamente: «Es una ironía llamar unión libre a una pareja en la que el hombre es un déspota y un tirano zafio, capaz de degollar a la mujer si la coge besando a otro hombre, o, cuando menos, olvidarla y maltratarla» ${ }^{0}$. Esta

${ }^{8}$ Bajatierra, 1934, p. 46; Estudios, 128, abril de 1934, p. 32; Estudios, 122, octubre de 1933, p. 43; Estudios, 92, abril de 1931, p. 34; Acracia, 307, 19-07-1937, p. 12; La Revista Blanca, 229, 01-12-1932, p. 408; Solidaridad Obrera, 438, 08-06-1932, p. 5; Butlletí C.N.T.-F.A.I., 10, 06-03-1937, p. 9; El Sembrador, 77, 08-09-1932, p. 3; Estudios, 77, enero de 1930, p. 25; Nash, 1981, pp. 37-47. En todo este encomio del amor libre, por omisión se infiere que las parejas debían ser heterosexuales, sin que se contemplase la existencia de relación amorosa alguna entre personas del mismo sexo. La realidad muestra que, a pesar de la retórica libertaria en favor de la libertad individual, se mantenía cierta visión peyorativa acerca de la homosexualidad que, si bien no llegaba a ser tachada de inmoral o a condenar a sus practicantes, se la consideraba una práctica antinatural como consecuencia de una alteración fisiológica. Lora Medina, 2015, pp. 207-224.

9 Solidaridad Obrera, 105, 07-01-1933, p. 4; La Revista Blanca, 267, 01-03-1934, p. 254; Estudios, 87, noviembre de 1930, p. 15; Solidaridad Obrera, 112, 04-03-1933, pp. 3, 4.

10 Gallardo, s.d., p. 4. 
exigencia y la necesidad de establecer unas bases conceptuales homogéneas para todo el movimiento cenetista llevaría a la presentación de la ponencia sobre el concepto confederal de comunismo libertario en el IV Congreso de la CNT, celebrado en mayo de 1936 en Zaragoza, en un clima social abiertamente revolucionario y de preguerra civil. Dicho dictamen, presentado por Alejandro Gilabert, Francisco Tomás y Nemesio Galve - en representación del Sindicato del Ramo de la Construcción de Barcelona-, abordaba como un todo las relaciones sexuales, el amor libre y la familia para establecer la plena autonomía y libertad del individuo en la práctica personal. Sin embargo, ello no impedía que se considerase abolido el matrimonio burgués y se remarcaran dos pautas que debían regir la vida de la pareja libertaria, la ética anarquista y la higiene personal ${ }^{11}$.

A pesar de establecerse unas pautas generales, la organización confederal optaba por que cada individuo obrara de acuerdo con sus propios dictados y asumiera la responsabilidad de sus actos. Esta exigencia de un comportamiento moral y ético inmaculado, extendido al ámbito sentimental, era una reivindicación clásica del anarquismo en tanto que la fuerza de sus ideas se visibilizaba en el ejemplo vital de sus militantes. La apología del amor libre trasciende lo puramente afectivo para significar la lucha anarquista por la existencia de su sociedad ideal, de ahí que se combata la cultura burguesa, la prostitución, el adulterio, la castidad, la masturbación, la moral religiosa en materia sexual, en definitiva, los aspectos tradicionales en los que se había manifestado hasta entonces todo lo referente al ámbito del amor y la sexualidad ${ }^{12}$.

De este modo, los matices y las interpretaciones acerca del amor libre acababan siendo tantas como individuos integraban el movimiento libertario, de ahí que quepa preguntarse ¿qué entendían realmente los propagandistas libertarios cuando hablaban de «amor»? Se trata de una pregunta compleja que necesita de la suma de las distintas visiones particulares para abordar un sentimiento que acaba trascendiendo el simple carácter de afinidad sentimental o genésica.

Para Augusto M. Alcrudo, masón y médico libertario asesinado en septiembre de 1936, el amor supera las barreras de lo puramente físico y de lo estrictamente sexual. Mientras que Sara Berenguer, afiliada a la

11 Solidaridad, 44, 25-04-1936, p. 4.

12 Estudios, 78, febrero de 1930, p. 10; Estudios, 89, enero de 1931, p. 38; Fuchs, 1996, pp. 21, 188; Lora Medina, 2018, pp. 134-163. 
CNT y Mujeres Libres durante la guerra, lo interpreta como un sentimiento superior de atracción que nace del amor puro y que se concreta en una estima íntima hacia la otra persona. Se interpreta como un concepto filosófico que trasciende el individualismo para adquirir una connotación eminentemente social que antepone el beneficio colectivo al bien individual o personal ${ }^{13}$. Esta idea es la que subyace en el diálogo que mantienen un obrero preso con una joven novicia encargada de la enfermería de la prisión en la novela social de Francisco Caro Crespo, «El último baluarte»: «Amo más que vos, porque yo amo a la humanidad en su conjunto y a todas horas. Para mí no hay momento de reposo en este amor humano» ${ }^{14}$.

Para Federico Urales y Antonia Maymón es un sentimiento que impulsa al sacrificio en favor del ser amado. Se trata de una idea que supera los límites de un simple sentimiento afectuoso cual sustancia espiritual y psíquica, originada en el cerebro humano, a través de la que se alcanza el goce supremo de la vida. Su esencia básica es la libertad y es equiparado a los conceptos de vida, progreso y bondad, sinónimos a su vez de lo bello y lo bueno que se entrelazan para acercar a la humanidad al triunfo de la obra social futura. Es una fuerza interior que exhorta a abandonar la tradición, la riqueza, la familia o la tierra y que compele a los amantes, como los de la novela Huyamos! de Ángel Pestaña a preferir la pobreza a la desunión ${ }^{15}$ : «El amor encierra en sí lo que de más sublime tiene el hombre: la serena y la plácida inclinación a lo bello, que le hace elevarse, con afán superador $[. ..]{ }^{16}$. Juan Frax Tejedor - anarquista vasco afiliado a la FAI-, define el amor como «la atracción y comunión de dos cerebros, de dos corazones, de dos sensibilidades» ${ }^{17}$; para Federica Montseny es «comunión de almas» y «néctar y ambrosía del espíritu» en opinión de Higinio Noja.

13 Estudios, 113, enero de 1933, p. 53; Berenguer, 1984, pp. 172, 173; El Sembrador, 1, 25-06-1930, p. 2.

${ }^{14}$ Francisco Caro Crespo fue un joven anarquista jerezano, aficionado a la novelística y la dramaturgia, que falleció en 1927 de tuberculosis. Enfermedad que se le agravó tras ser encarcelado acusado de participar en el golpe de Estado de 1926 contra el dictador Primo de Rivera. Caro Crespo, 1927, pp. 11, 12; Íñiguez, 2001, p. 126.

${ }_{15}$ La Revista Blanca, 102, agosto de 1927, p. 175; Estudios, 92, abril de 1931, p. 34; Estudios, 85, septiembre de 1930, p. 20; El Sembrador, 111, 29-12-1933, p. 3; Estudios, 86, octubre de 1930, pp. 18, 19; Estudios, 89, enero de 1931, p. 16; Pestaña, 1935 , p. 32 .

16 Brazo y cerebro, 14, 01-12-1935, p. 3.

17 Brazo y cerebro, 23, 01-05-1936, p. 4. 
Es una inclinación natural del ser humano y herramienta básica para hacer del individuo un ser más tolerante, comprensivo, natural y solidario ${ }^{18}$.

Es un amor elevado a una concepción platónica como sensibilidad noble y sincera que transforma y libera al ser que lo abraza, al tiempo que persigue la erradicación de todo principio de autoridad o coacción en la pareja. En esta línea, los celos tampoco tienen cabida bajo esta percepción, por ser sentimientos asociados a una mentalidad tradicional que sólo persigue el disfrute del cuerpo del ser amado de forma egoísta. Para la maestra racionalista Armelina Alsina, son claramente producto de la herencias religiosa y la moral autoritaria del pasado mientras que, en opinión de Mariano Gallardo y Javier Serrano, son la manifestación de una sexualidad enfermiza. Esto lleva a que sean definidos como un prejuicio burgués resultado de la falta de educación y de un espíritu autoritario, que lo convierte en un instrumento más de dominación sexual que rompe la teórica igualdad de los sexos. Federica Montseny los denomina «los celos que matan» ya que no proceden del amor sino del autoritarismo, mientras que para Luis Bonilla son «irracionales», psicológicamente más complejos y difíciles de abordar porque retuercen el sentimiento amoroso y lo transforman en instinto de posesión. Estos celos se contraponen con los que Montseny denomina «perfume y espinas del amor» y que considera inofensivos. Son los «celos naturales» o «lógicos», según Bonilla, basados en un sentimiento egoísta y de tristeza por parte de la persona rechazada, pero que al ser naturales serían menos peligrosos ${ }^{19}$.

Los propagandistas libertarios definían el amor libre como una relación amorosa de intenso sentimentalismo que nace y termina en el individuo pero que persigue el establecimiento de una compenetración íntima con la otra persona. Al deslegitimarse los elementos materiales como causa u origen del vínculo, adquieren una gran relevancia elementos ético-sentimentales como la libertad y la igualdad, el respeto y la tolerancia, la pasión y la atracción física, que debían centrar la vida en pareja y que ésta, a su vez, debía irradiarlos a la sociedad a través

${ }^{18}$ La Revista Blanca, 18, 15-02-1934; Estudios, 77, enero de 1930, p. 25; Crisol, 5, 18-01-1936, p. 4.

19 El Porvenir del Obrero, 24, 27-02-1932, p. 3; Gallardo, M., El sexo, la prostitución, el amor, pp. 7, 8; Solidaridad Obrera, 579, 08-12-1932, p. 2; Iniciales, 9, septiembre de 1934, pp. 6, 7; La Revista Blanca, 272, 06-04-1934, p. 335; El Porvenir del Obrero, 30, 09-04-1932, p. 3; La Revista Blanca, 108, noviembre de 1927, pp. 367, 368; Estudios, 125 , enero de 1934, pp. 15, 16. 
del ejemplo personal. Sin embargo, la teoría se topaba en muchas ocasiones con la realidad de una sociedad en la que, incluso entre muchos militantes libertarios, pervivía una visión fuertemente masculinizada de la sexualidad, que llevaba a que muchos hombres se valieran de su «carnet» de anarquistas para consumar relaciones sexuales con mujeres a las después abandonaban escudándose en el «amor libre» ${ }^{20}$.

La permanencia de estos comportamientos hacía que muchos libertarios juzgaran el amor libre como una práctica demasiado peligrosa por las consecuencias negativas que podían derivarse de ella, además de por miedo al escarnio público. En este sentido, las mujeres eran las que más tenían que perder debido al riesgo que suponía quedarse embarazada de unos hombres que, al no tener «obligaciones legales» con ellas, podían abandonarlas cuando quisieran. El estigma social que suponía un hijo ilegítimo, unido a la posibilidad de ser repudiadas por haber deshonrado a su familia, dejaba a la mujer libertaria en una situación muy complicada. Incluso Javier Serrano, desde La Revista Blanca, alertaba a las mujeres de que se guardasen de unirse con hombres hacia los que únicamente les unía la atracción física, sugiriéndoles buscar una relación basada en un verdadero sentimiento amoroso. Mientras criticaba a los varones que cambiaban de compañera únicamente por el disfrute sexual de un cuerpo joven, acusándolos de libertinaje. En definitiva, sexo libre sí, pero con sentimientos ${ }^{21}$.

\section{La unión libre: entre la Segunda República y la Guerra Civil}

El debate sobre el amor libre no se iba a centrar únicamente en su apartado teórico, sino que se abordaría también su dimensión práctica,

${ }^{20}$ La preeminencia del varón seguía inmersa en la mente de muchos libertarios, tanto hombres como mujeres, que difunden una imagen de éstas como seres débiles, conservadores y dependientes. Por contra, el hombre suele ser mostrado como salvador y maestro de la fémina desamparada, humillada y maltratada por una sociedad que la oprime y discrimina. Al tiempo mismo tiempo, no se encuentran noticias a la inversa en las que se exalte la altura moral de la mujer como redentora del varón. Un ejemplo es el caso del cenetista catalán Francisco Catasús, en cuyo panegírico publicado en El Sembrador de Igualada se señala que «[...] estaba unido libremente con una muchacha que él supo capacitar, repulir y elevar hasta convertirla en su leal y digna compañera de por vida». El Sembrador, 114, 24-02-1934, p. 4.

${ }_{21}$ Estudios, 81, mayo de 1930, p. 22; La Revista Blanca, 275, 26-04-1934, p. 383; La Revista Blanca, 255, 07-12-1933, p. 15; La Revista Blanca, 287, 20-07-1934, p. 572. 
surgiendo así dos tipos diferenciados y opuestos de unión: la monogamia y el pluralismo 22 . Aunque cada una contaba con sus partidarios y detractores, anarquistas como Mariano Gallardo o Javier Serrano señalaban que la idiosincrasia ácrata imponía el respeto a la libertad de elección de cada uno, sin que pudiera establecerse una forma correcta o incorrecta de unión: «Unos sienten el amor de una manera y otros de manera distinta. Por esto no podemos decir que un amor plural valga más que otro singular» ${ }^{23}$. Sin embargo, ello no fue óbice para las críticas mutuas ya que, aunque no les separaban cuestiones doctrinales, sí se diferenciaban en la percepción acerca de qué tipo de unión atesoraba más cantidad de libertad y menos de autoritarismo. Los valedores de la poligamia amorosa condenaban la monogamia por ser una relación basada en la avaricia y la posesión de la pareja, denunciando el mantenimiento de las formas de relación tradicionales y la falta de libertad sexual. Mientras, los adalides de la monogamia criticaban el pluralismo como una llamada libre a la promiscuidad, una alabanza viciosa del sexo despojado de todo sentimiento y en la que la mujer era percibida como simple objeto sexual masculino. Sin embargo, los argumentos en beneficio de cada una de estas opciones amorosas eran más complejos de lo que sus detractores evidenciaban ${ }^{24}$.

Los defensores del amor plural conciben la unión como una experiencia vital que debe conducir al practicante al deleite de la belleza absoluta del amor a través del sexo. Esta catarsis debía realizarse expresamente a través de la comunión física con muchas parejas sexuales para que fuera un proceso de aprendizaje colectivo y continuo. Para sus practicantes, el amor-sexual no debía ser prefijado - uniones monógamas - ,

22 El pluralismo, también conocido como amor plural, es el término utilizado para definir la opción amorosa anarquista que se inclinaba por una visión liberadora del sexo y que cosificaba la idea de libertad como una práctica que debía abarcar especialmente la faceta sexual de la mujer y el hombre anarquistas. Bajo esta visión, las relaciones de pareja monógamas eran criticadas porque oprimían al individuo, convertían el amor en algo estrictamente mercantil y el principio de la propiedad privada. Se trataba de una opción considerada la solución a los celos, la prostitución y el único tipo de relación garante de la libertad tanto de hombres como de mujeres. Entre sus principales propagandistas a nivel internacional se encontraban Émile Armand, Han Ryner o María Lacerda de Moura Estudios, 129, mayo 1934, p. 22; Estudios, 132, agosto 1934, p. 19; Nash, 1981, p. 51; Díez, 2007, p. 255.

${ }^{23}$ La Revista Blanca, 278, 18-05-1934, p. 429.

${ }^{24}$ La Revista Blanca, 386, 30-06-1936, p. 54; Díez, 2007, pp. 64, 65, 130, 131, 260. 
ni canalizado hacia fines concretos - procreación-, ni debía temerse el rechazo público pues su cometido último y revolucionario era provocar con su comportamiento que la sociedad se replanteara su sistema de valores como arcaico e inmoral. Para sus defensores era la única unión que garantizaba la verdadera igualdad sexual entre hombres y mujeres, ya que el sexo era identificado como una necesidad que no podía ser reprimida, sino que tenía que ser experimentada al máximo. Esta línea interpretativa del amor libre estaba en consonancia con las ideas del anarquismo individualista y entre sus seguidores principales se distinguían dos tendencias incuestionables. Una, la defendida por la anarquista brasileña María Lacerda de Moura que divulgaba la visión del «amor plural» del francés Han Ryner. Y la otra, apoyada en España por Mariano Gallardo, se basaba en la llamada «camaradería amorosa» del también anarcoindividualista francés Émile Armand ${ }^{25}$.

En cuanto al amor singular, la realidad social y la tradición facilitaron que la mayoría de militantes se inclinasen por aquellas uniones a las que estaban más habituados. Razón por la cual, dado que fue el tipo de unión mayoritaria entre los anarquistas españoles de los años treinta, vamos a centrarnos en ella principalmente. Esta era considerada la más perfecta de las uniones porque, a diferencia del matrimonio tradicional o el amor plural, no esclavizaba a la mujer al garantizar su plena libertad de elección. El fermento de la unión era la búsqueda de la comunión moral, sentimental y física de los amantes. La pareja debía basar su convivencia en principios como el altruismo, la solidaridad, la igualdad y la comprensión mutua y, por tanto, debía ser necesariamente voluntaria, amorosa y desinteresada ${ }^{26}$.

Para Félix Martí Ibáñez la «monogamia excelsa» es el tipo de relación donde mejor se interrelaciona el amor como sentimiento y el sexo como impulso biológico. Antonio Llauradó e Higinio Noja la estiman como la unión ideal que humaniza las costumbres y es la más acorde con las leyes de la naturaleza. Mientras, Federica Montseny opina que toda relación basada en la convivencia permanente de los amantes desgasta el sentimiento que la vertebra y es contraproducente para su perduración. La anarquista madrileña defiende lo que denomina el «individualizamiento» como solu-

25 Estudios, 128, abril de 1934, pp. 24, 25; Gallardo, s.d., pp. 3-48; Díez, 2007, pp. 64, 65, 260.

${ }_{26}$ Solidaridad Obrera, 1076, 27-09-1935, p. 8; La Revista Blanca, suplemento al n. 274, 12-04-1934, p. III; Solidaridad Obrera, 110, p. 4; García Maroto, 1996, p. 136. 
ción para evitar el fin del sentimiento en la pareja, que viene a significar la no convivencia de los amantes. Javier Serrano, aunque alineado teóricamente con el pluralismo amoroso como símbolo de la libertad sexual completa, estima que su implantación en la sociedad acabaría derivando en una visión de la mujer como objeto sexual. Su apuesta por la monogamia amorosa se realiza desde un enfoque pragmático, como hace también Valentín Obac, para el que la fortaleza de estas uniones reside en poder ponérseles fin en cualquier momento ${ }^{27}$.

Bajo la retórica ácrata, la unión libre monógama nunca puede ser equiparable al matrimonio civil en tanto que ello supondría la aceptación del Estado como garante último de la unión. Por esta razón, aunque la Constitución de 1931 salvaguardaba el derecho de disolver el casamiento con arreglo a la ley, el divorcio era valorado como un retroceso en la libertad de los cónyuges porque el dictado de la separación recaía, en última instancia, en el ordenamiento jurídico del país y no en el individuo. Para Amparo Poch y Gascón estas cuestiones pertenecen exclusivamente al ámbito privado de la pareja y del mismo modo que se trata de un vínculo realizado sin necesidad de ceremonia oficial, la disolución de la misma debía ser igual de espontánea, de lo contrario sería como hacer del amor «el alquiler de una finca» ${ }^{28}$. Por otro lado, José Villaverde critica a los que confunden amor con sexo y se olvidan de cimentar una relación espiritual basada en la compenetración de los amantes: «No hay que confundir; amor libre, o sea libre unión, con esos amancebamientos que solo tienen como finalidad un grado más en el camino de la prostitución» 29 .

La realidad es siempre mucho más compleja que la ficción, y ésta evidencia especialmente numerosas fricciones con el ideal. Había anarquistas que, antes de la instauración de la Segunda República y por presión social o familiar, se habían casado por la Iglesia y ahora, en la década de los treinta y con la CNT y FAI legalizadas, preguntaban si

${ }_{27}$ Nash, 1981, p. 50; Ackelsberg, 1999, p. 203; Espigado Tocino, 2002, p. 62; Espigado Tocino, 2004, p. 482; Estudios, 92, abril de 1931, p. 17; Estudios, 134, 1934, p. 14; Estudios, 108, agosto de 1932, p. 36; Estudios, 87, noviembre de 1930, p. 15; La Revista Blanca, 93, 01-04-1927, pp. 656-659; La Revista Blanca, 94, 15-04-1927, pp. 679-682; La Revista Blanca, n. ${ }^{\circ}$ 287, 20-07-1934, p. 572; Estudios, 81, mayo de 1930, p. 25; Estudios, 87, 1930, p. 27.

28 Solidaridad Obrera, 1076, 27-09-1935, p. 8.

29 Solidaridad Obrera, 105, 07-01-1933, p. 4. 
podían considerarse realmente anarquistas. Según La Revista Blanca en 1934, aquellos que no conocieran las ideas libertarias en el momento del casamiento podían apreciarse como tales, pero los que hubieran contraído tal matrimonio siendo ya ácratas, manifestaban una debilidad moral e ideológica que no les hacía merecedores de serlo. Esta postura despertaba muchos interrogantes en aquellos militantes que, como «Uno que quiere ser libre», estaban enamorados de mujeres de firmes ideas católicas que sólo contemplaban el matrimonio eclesiástico como base de su unión. La revista, que anteponía el puritanismo ideológico al individuo, le recomienda que se olvide de ella y busque una compañera afín ideológicamente ${ }^{30}$.

Otro de los asuntos que más debate generó en los medios confederales fue el relativo a la libertad sexual. La mayoría de las consultas realizadas sobre este particular, en concreto sobre si una mujer podía tener relaciones con varios hombres o qué hacer al descubrir que tu compañera no era virgen, denotan que seguía sin asumirse realmente un verdadero igualitarismo. Lucía Sánchez Saornil, una de las fundadoras de Mujeres Libres, en una discusión mantenida a través Solidaridad Obrera sobre el papel de la mujer en el anarquismo con Mariano Rodríguez Vázquez, entonces secretario del sindicato de la construcción de la CNT barcelonesa, denunciaba la demagogia de muchos libertarios que, aunque a nivel teórico defendían el igualitarismo, en la práctica mantenían una doble moral sexual escudándose en la tradición. La prensa confederal, en su afán por favorecer la libertad de opinión y el surgimiento de debates que enriquecieran doctrinalmente a la militancia, permitía también la publicación de artículos que ofrecían argumentos contradictorios como el escrito por R. P. en Solidaridad Obrera, en el que señalaba que la culpa de la situación de la mujer no era exclusiva del hombre, sino de la sociedad en su conjunto. Este artículo, que mereció también la réplica y la denuncia de Sánchez Saornil, recogía la opinión de una parte de la afiliación de que la mujer si no se había emancipado era por su propia culpa ${ }^{31}$.

${ }^{30}$ La Revista Blanca, suplemento al n. ${ }^{\circ} 277,11-05-1934$, p. V; La Revista Blanca, 296, 21-09-1934, p. 725.

31 Solidaridad Obrera, 1075, 26-09-1935, p. 2; Solidaridad Obrera, 1053, 31-081935, p. 2; Nash, 1981, p.26; Nash, 1999, p.225; Ackelsberg, 1999, pp.161, 162; Sanfeliu, 2012, pp. 331-346. 
Otro de los problemas existentes iba a ser el desconocimiento de muchas mujeres acerca de los fundamentos teóricos del amor libre, como lo demuestran las preguntas realizadas al consultorio de $\mathrm{La} \mathrm{Re}$ vista Blanca. En 1935, «Una bandida sin carnet» preguntaba si una mujer casada a la fuerza con un burgués que la había abandonado a los seis meses podía relacionarse sentimentalmente con otro hombre: «Puede, desde luego. Y sería una verdadera lástima que no intentase reconstruir su vida con otro hombre, capaz de amarla y comprenderla ${ }^{32}$. El desconocimiento y la negativa a asumir este tipo de comportamientos amorosos por parte de la militancia, se contraponía con la existencia de anarquistas que asumían el carácter ejemplarizante de su comportamiento y aceptaban los riesgos de unirse libremente. Este fue el caso de la libertaria catalana Lola Iturbe, unida libremente primero con Faustino Vidal, un cenetista que conoció militando en el grupo de afinidad «Germen», con el que tuvo una hija llamada Aurora, pero que la tuberculosis, como a tantos obreros encarcelados por sus actividades revolucionarias, acabaría quitando la vida. Y, en segundo lugar, con Manuel Molina «Juanel», también compañero del mismo grupo, anarquista del sector ultraestatista de la FAI y secretario de la misma entre 1930 y 1935, con el que compartiría el resto de su vida y tendría otro hijo llamado Helenio. Este tipo de uniones suelen ser una costumbre entre los dirigentes y personalidades más destacadas del anarcosindicalismo español, lo que demuestra el compromiso de parte de la militancia por vivir el amor libre desde el propio ejercicio del mismo ${ }^{33}$.

La lucha por hacer extensiva esta práctica de las uniones libres superaba el ámbito personal para convertirse en objeto específico de divulgación por parte de todos los sectores componentes del asociacionismo libertario: grupos de jóvenes anarquistas, ateneos libertarios, secciones de

32 La Revista Blanca, 330, 17-05-1935, p. 479.

${ }^{33}$ Lora Medina, 2018, pp. 181-203; Fontanillas \& Torres, 2006, pp. 40, 41. Entre los que destacan nombres como Buenaventura Durruti (con Émilienne Morin), Federica Montseny (con Germinal Esgleas), Augusto Moisés Alcrudo Solórzano (con Agustina Andrés), Progreso Fernández (con Concha Estrig), Pedro Vallina (con Josefina Colbach), María Silva La Libertaria (con Miguel Pérez Cordón), Mercedes Comaposada (con Baltasar Lobo), Galo Díez (con Claudia Maza), David Antona (con María Isabel González), Francisco Ascaso (con Carmen Zaragoza), Suceso Portales Casamar (con Acracio Ruiz), Sara Berenguer (con Jesús Guillén), José Pellicer Gandía (con María de las Mercedes Veloso) y Mariano Rodríguez Vázquez (con Concha Dávila), entre tantos otros, se habían unido sentimentalmente conforme a la «norma» libertaria. 
cultura de los grupos de afinidad, las Juventudes Libertarias y los propios sindicatos. Cada uno de estos colectivos organizaba de forma autónoma, según sus posibilidades y número de miembros, eventos destinados a divulgar las bondades del amor libre. Las actividades más prolíficas eran las charlas y conferencias en las que un militante conocido de la ciudad o la región exponía su visión del amor y la sexualidad, ya que permitían debatir y poner en común las dudas, certezas y miedos que existían sobre dicha práctica. Son actos como el celebrado a finales de 1931 en el local del Sindicato del Arte Fabril y Textil de Barcelona y organizado por el Ateneo Libertario del Clot, en el que José Robusté, propagandista destacado y redactor de Solidaridad Obrera, disertaba sobre «La mujer y el amor» reivindicando que el amor libre era mucho más que casarse por la iglesia o el Estado, era la verdadera igualdad sexual entre hombres y mujeres. El contenido de estas disertaciones ofrece una imagen general de cuáles eran las verdaderas limitaciones y problemáticas existentes entre la militancia, manifestándose que el problema era más de fondo que de forma ${ }^{34}$.

El objetivo de estas conferencias era profundizar en los distintos aspectos del habitus anarquista acerca de su concepción del amor, en una labor que no nace en los años treinta sino que viene heredada de décadas pasadas a través de la labor de anarquistas como Federico Urales, Galo Díez o Soledad Gustavo que a través de la prensa y la publicación de novelas o la impartición de charlas extendieron desde finales del siglo XIX la teoría y la práctica del pensamiento amoroso anarquista. Así, «el amor desde el punto de vista humano», «amor libre e higiene sexual», «amor y moral», «unión libre y matrimonio legal»o «amor libre y amor mercenario» fueron algunas de estas charlas organizadas por ateneos y grupos anarquistas durante los años de la Segunda República y la Guerra Civil a las que se pretendía dar siempre un enfoque científico y totalizador. Se pretendía persuadir a la militancia de que el amor y la unión libre eran sinónimos de una vivencia natural y sana de las relaciones sentimentales, al tiempo que denunciar la sociedad burguesa, la moral católica, la persistencia de comportamientos tradicionales en cuanto al sexo y reflejar que la revolución no solo era social, sino necesariamente interna ${ }^{35}$.

34 Solidaridad Obrera, 324, 04-12-1931, p. 7.

35 Solidaridad Obrera, 243, 29-08-1931, p. 7; Solidaridad Obrera, 438, 09-06-1932, p. 7; Solidaridad Obrera, 837, 12-04-1934, p. 5; Solidaridad Obrera, 888, 09-08-1934, p. 5; Solidaridad Obrera, 1537, 17-03-1937, p. 11. 
La propaganda escrita se complementaba con otras iniciativas culturales como la celebración de cursos, como el celebrado entre noviembre de 1934 y enero de 1935 por la Asociación de Idealistas Prácticos de Barcelona, e impartido por Félix Martí Ibáñez. La temática central versaba sobre moral sexual y amor libre, y reunió a un total de 104 asistentes entre los que participaron 44 mujeres y 60 hombres. Uno de los principales intereses de Martí Ibáñez fue sondear el grado y la profundidad de conocimiento de los participantes a través de pequeños cuestionarios con respuestas prefijadas:

\section{Pregunta 1}

«¿Cree usted que el problema sexual puede ser resuelto mediante ciertas reformas practicadas en la actual institución matrimonial? ¿O bien se pronuncia usted por la libertad de amar en forma monógama o por la camaradería amorosa?»

\section{Pregunta 2}

«¿Cuál cree usted que es la fórmula ideal de convivencia sexual: la monogamia o la poligamia en forma de camaradería amorosa? ¿Por qué lo cree y sobre qué bases estructuraría usted la unión preferida?»

\section{Posibles respuestas}

- Por el matrimonio actual

- Por la camaradería amorosa (poligamia y poliandria)

- Por una cultura sexual amplia, a base de la cual cualquier tipo de unión sería aceptable

- Por el amor libre en forma monógama 


\section{Tabla I}

Respuestas de los participantes al curso de moral sexual.

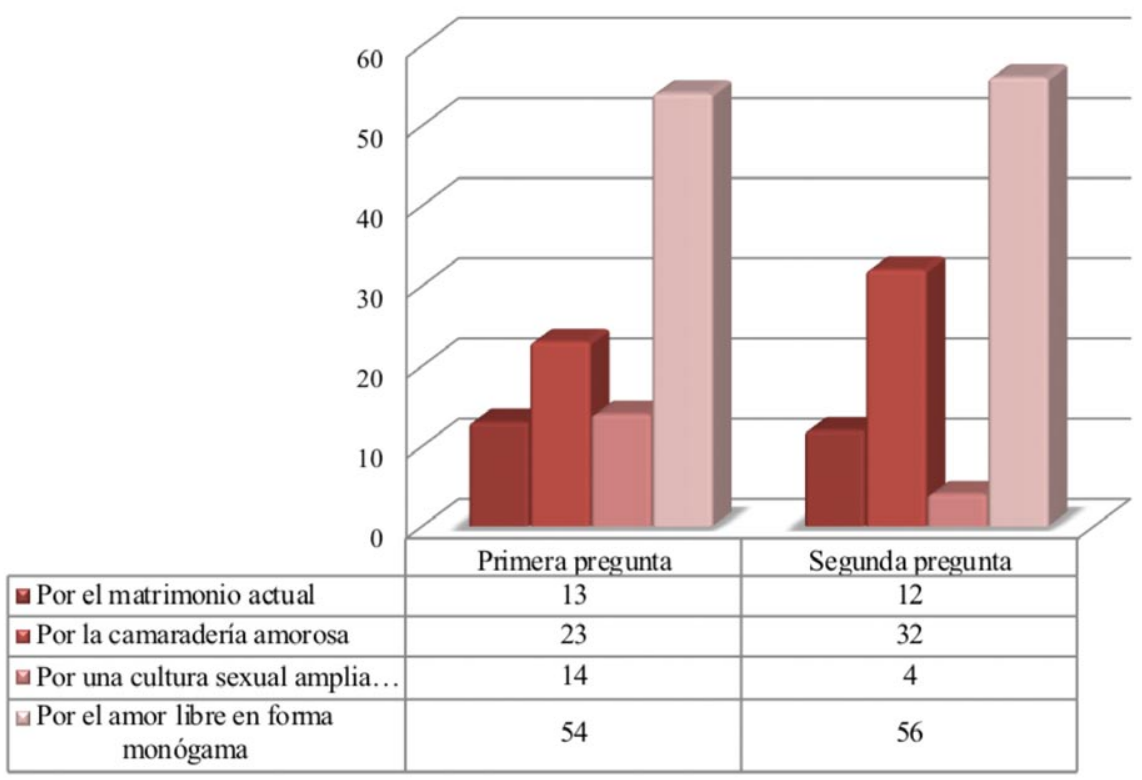

Fuente: Estudios, n. ${ }^{\circ}$ 141, mayo 1935. 1-24. Elaboración propia.

El resultado de la encuesta, aunque no es extrapolable por tratarse de un colectivo muy reducido, sirve para analizar la incidencia que estas ideas tenían socialmente, especialmente entre la juventud. El hecho de que la unión monógama sea la respuesta más habitual entre los jóvenes encuestados demuestra que la propaganda para extender el amor libre surtía efecto, al menos entre algunos colectivos. Las respuestas a la segunda pregunta muestra que el 54\% considera que la unión libre monógama es la forma ideal de convivencia sexual, principalmente porque siendo la opción menos rupturista con el formato tradicional de pareja es también revolucionaria, por lo que su aplicación sería más fácil de adaptar que la camaradería amorosa. Eso es precisamente lo que la convierte en la opción preferida, más entre las mujeres (64\%) que entre los hombres $(47 \%)$. Por otro lado, mientras un porcentaje residual (12\%) seguía 
prefiriendo como forma ideal de relación el matrimonio tradicional, la camaradería amorosa con un $31 \%$ del apoyo era la opción preferida por los varones. Sólo 8 mujeres de 44 (18\%) preferían un pluralismo sexual que, en una sociedad en la que la pervivencia de las ideas conservadoras y la existencia de un fuerte prejuicio sexual hacia la mujer, conllevaría el escarnio público ${ }^{36}$.

Los convencionalismos sociales, esos habitus de pensamiento tradicionales tan presente en el subconsciente social, eran un gran obstáculo para muchos anarquistas que deseaban construir una relación sentimental basada en las ideas del amor libre. El hombre se encontraba con el inconveniente de encontrar mujeres «liberadas» que asumieran el riesgo de unirse con hombres supuestamente liberados, sin más seguridad que la confianza y las palabras mutuas de fidelidad y comprensión. Por contra, las mujeres favorables a estas uniones eran escasas porcentualmente, no sólo por los impedimentos ya aludidos, sino especialmente por su exigua participación y presencia en la vida sindical y cultural de los grupos de afinidad, espacios masivamente ocupados por los varones. La existencia de claros sesgos de género, más en la concepción práctica del amor libre que en su dimensión teórica, estaba intrínsecamente relacionada con la permanencia del pensamiento tradicional más en la mujer que en el hombre. Ésta se encontraba más atenazada que el varón en cuestiones sexuales por la persistencia de una moral religiosa que la reprendía por querer disfrutar de los beneficios de la carne. Esto evidenciaba que, a pesar de la retórica ácrata, seguía muy presente el habitus que hacía de la mujer la madre, la esposa y la hija fiel e ideal del hombre, incluso entre los anarquistas $^{37}$.

Sin embargo, desde los medios libertarios, conscientes de esta realidad, se actuaría en consecuencia para lograr facilitar la extensión de una práctica que debía llevar a un cambio de paradigma y de concepción de las relaciones de pareja. La Revista Blanca intentaría paliar esta deficiencia con una iniciativa ideada por Javier Serrano que permitiría a hombres y mujeres afines ideológicamente encontrar una pareja. En mayo de 1934, en respuesta a un lector de La Revista Blanca, el $D r$. Klug proponía la idea de realizar anualmente una fiesta del amor

\footnotetext{
36 Estudios, 141, mayo de 1935, pp. 24-27.

37 García-Maroto, 1996; Lora Medina, 2017, pp. 170, 171.
} 
libre con la impartición de conferencias de divulgación sexual y otras actividades que deberían ser impulsadas y anunciadas por la prensa para aumentar su extensión entre la militancia libertaria. Sólo un mes después, la redacción de la revista agradecía los consejos del médico libertario y se comprometía a crear un apartado de contactos dentro de su sección «Consultorio general» junto a la propuesta de realizar jiras comarcales y convertir el Primero de Mayo en la gran fiesta del amor libre ${ }^{38}$.

La sección de contactos, publicada entre julio de 1934 y noviembre de 1935, era un formato novedoso para la prensa libertaria y prometía «publicar las direcciones de cuantos jóvenes quieran y no puedan por falta de mujeres casarse libremente ${ }^{39}$. Aunque estaba dirigido tanto a hombres como mujeres, por seguridad de éstas y para evitar ser objeto de persecución u hostigamiento, solo los varones debían enviar sus datos personales a la revista. Se prefería que fueran ellas las que contactaran directamente con los hombres que les interesaran. Este modo de proceder dejaba a la mujer la potestad para decidir cuándo y con quién quería relacionarse, empoderándolas como sujetos activos de su vida sexual. La revista recalca que el objetivo principal eran las «relaciones amorosas», dejando fuera todos aquellos anuncios que tuvieran una finalidad distinta ${ }^{40}$ :

«Para evitar que haya abusos y engaños en estas relaciones entabladas por correspondencias o de palabra, rogamos a las mujeres que las entablen, nos avisen, si el hombre con quien se relacionen con cualquier pretexto les pidiere dinero. También advertimos que si las mujeres que entablan estas relaciones tienen dudas sobre el propósito y la conducta de quienes se les dirigen, nos lo adviertan a nosotros que tenemos más facilidades para averiguar la clase de personas con las cuales se han relacionado» ${ }^{41}$.

\footnotetext{
38 La Revista Blanca, suplemento al 277, 11-05-1934, p. V.

39 La Revista Blanca, suplemento al 283, 22-06-1934, p. VII.

40 La Revista Blanca, 296, 21-09-1934, p. 725.

41 La Revista Blanca, 316, 08-02-1935, p. 141.
} 


\section{Tabla II}

Procedencia territorial de los interesados en sostener relaciones libres a través de La Revista Blanca

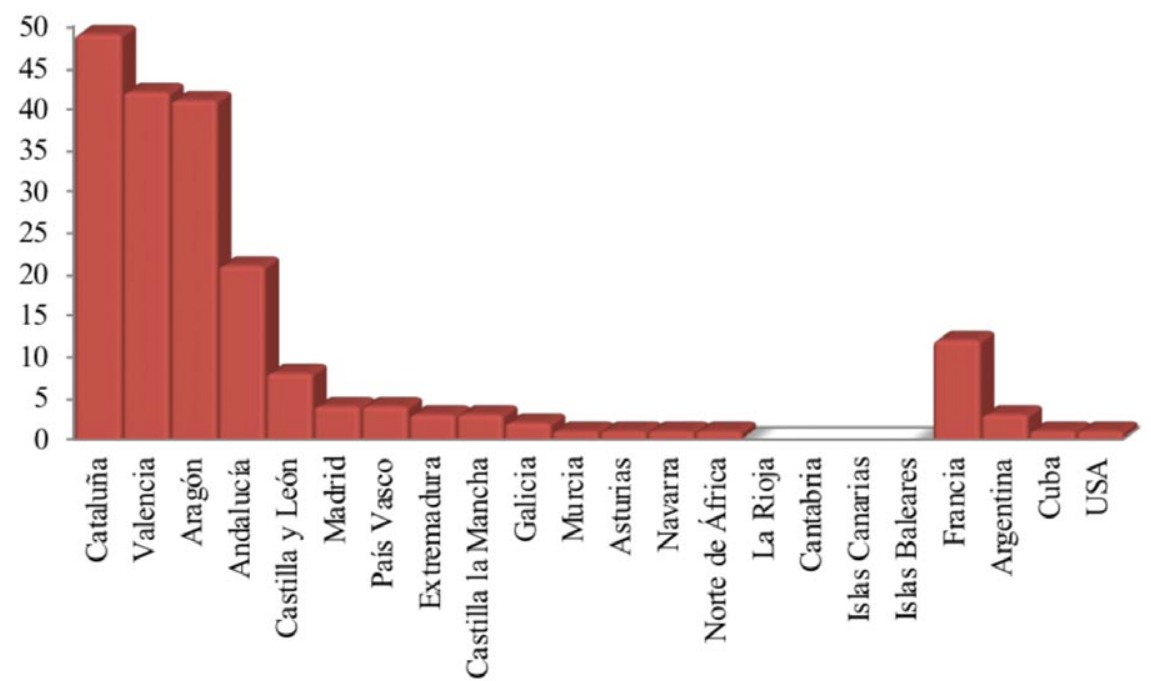

Fuente: La Revista Blanca, n..$^{\circ}$ 296, 21-09-1934 / n. ${ }^{\circ}$ 340, 26-07-1935. Elaboración propia.

Durante 28 números, 199 varones proporcionaron sus señas personales (nombre, apellidos, edad y lugar de residencia) para que la mujer iniciara una correspondencia que, no en todos los casos, acabaría teniendo éxito. Algunos añadían una pequeña descripción de sí mismos, indicando principalmente su oficio y circunstancias personales. Entre las profesiones más habituales destacaban aquellas relacionadas con el mundo agrario - campesinos, labradores y jornaleros - , además de un largo listado que albergaba una amplia diversidad de ocupaciones - mineros, metalúrgicos, carpinteros-ebanistas, ferroviarios, electricistas, tejedores, mecánicos, panaderos, zapateros, jardineros, etc.- . Había quienes señalaban los requisitos que debía reunir su futura compañera, como Germán Pueyo, 30 años y de Lérida, que le gustaría unirse con una joven de entre 20 a 30 años; Saturnino Samitier, de 31 y natural de Santa Eulalia de Gállego (Zaragoza), quería una «mujer de unos 25 años un poco culta»; y Francisco Hecho, de Cabañas de Ebro (Tarragona), se presentaba como estudioso e interesado en la música 
que buscaba una «mujer inteligente que conozca bien el ideal anarquista, a ser posible de aspiraciones artísticas ${ }^{42}$. También había quiénes, dado que no se publicaban fotografías ni ningún elemento visual, intentaban mostrar sus virtudes y características para resultar lo más atractivos posible: Fructuoso López de Ondara (Alicante), señalaba que, a pesar de sus 57 años, se conservaba físicamente bien y era vegetariano; dos jóvenes valencianos de 20 y 23 años, respectivamente, se declaraban practicantes del naturismo y el vegetarianismo; y tres amigos de Gandesa (Tarragona), de entre 20 y 21 años, señalaban que pertenecían a la Juventud Cultural local demostrando su compromiso con el ideal libertario ${ }^{43}$.

\section{Tabla III}

Edad de los interesados en sostener relaciones libres a través de La Revista Blanca

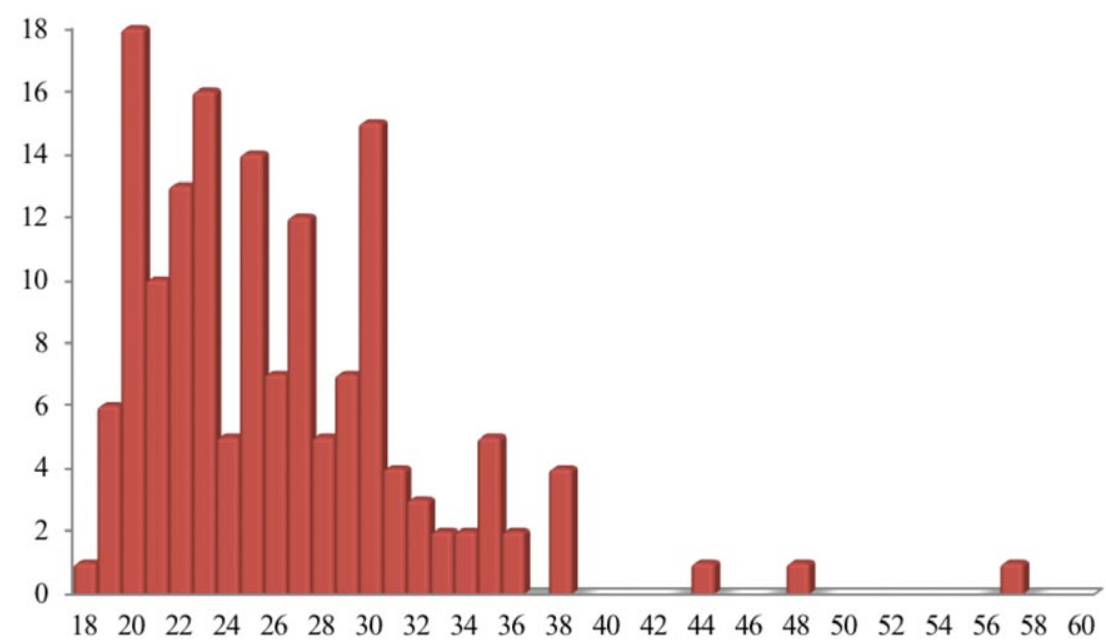

Fuente: La Revista Blanca, n. ${ }^{\circ}$ 296, 21-09-1934 / n. . 340, 26-07-1935. Elaboración propia.

42 La Revista Blanca, 300, 19-10-1934, p. 821 / 356, 15-11-1935, p. 1091; La Revista Blanca, 303, 09-11-1934, p. 894; 311, 04-01-1934, p. 22; 305, 23-11-1934, p. 942.

${ }_{43}$ La Revista Blanca, 305, 23-11-1934, p. 942; 311, 04-01-1934, p. 22; 337, 05-071935 , p. 647 ; 322, 22-03-1935, p. 285; 300, 19-10-1934, p. 821; 322, 22-03-1935, p. 285; $329,10-05-1935$, p. 455. 
La mayoría de los hombres participantes, como se muestra en la tabla II, procedían de Cataluña, la región por antonomasia del anarquismo español y centro de publicación de la revista. A renglón seguido, Valencia y Aragón eran las zonas geográficas más abundantes y colindantes con la región catalana, territorio de publicación de la revista por lo que no resultaría extraño. Sin embargo, el hecho de que en cuarto lugar esté Andalucía o hubiera libertarios que vivían en Francia, Argentina, Cuba o Estados Unidos demuestra la fortaleza editorial y prestigio de esta publicación tanto fuera como dentro de la península.

El análisis de la franja de edad de los varones refleja el triunfo del discurso libertario principalmente entre la juventud, según aparece reflejado en la tabla III. Se trata de un colectivo que había crecido influido por la presencia de la CNT y de destacados militantes que mantuvieron la propaganda a pesar de los periodos de clandestinidad durante los años veinte. La mayoría tienen entre 19 y 30 años lo que refleja el éxito de las ideas del amor libre entre los jóvenes, sector en el que el anarquismo sitúa todas sus expectativas de éxito futuro. La aprobación del matrimonio civil y de la ley de divorcio permiten consolidar un ambiente más propicio para aceptar cambios más profundos en las relaciones de pareja. A partir de los 35 años, la tendencia disminuye con apenas dos individuos de más de 40 y sólo uno de más de 50. Esta realidad demuestra que el amor libre era, en general, cuestión de jóvenes. Desafortunadamente, se trata de una estadística incompleta porque faltan los datos relativos a las repuestas de las mujeres por la política de la revista de salvaguardar su identidad. El hecho de que la revista avise a las mujeres de que contacten con los editores en caso de que algún hombre les pidiera dinero o tuvieran propósitos indignos, demuestra que posiblemente se hubiera dado algún acontecimiento parecido. El único anuncio femenino es el de R. Virginia Díaz, natural de Gandía, que se presenta como «Una mujer naturista, convencida, mediana cultura, ideal ácrata, viviría con compañero de 50 años, en adelante, de análogas condiciones ${ }^{44}$ y que decidió enviar sus señalas a la revista. Un caso extraordinario que muestra el prototipo de hombre que se busca: una persona con cierto conocimiento del ideal, aficionado a la lectura y la cultura, y que respetase a la mujer como una igual ${ }^{45}$.

${ }^{44}$ La Revista Blanca, 303, 09-11-1934, p. 894.

45 Vía Libre, 57, noviembre de 1937, p. 7; La Revista Blanca, 316, 08-02-1935, p. 141; Cleminson, 2008, p. 171; Díez, 2007, p. 66; Nash, 1995, pp. 285, 289. 
Se desconoce si la iniciativa de Javier Serrano acabó teniendo éxito, pero lo cierto es que cuando estas uniones fructificaban la prensa las divulgaba con un evidente tono aleccionador y de victoria moral. El periódico El Luchador de Barcelona se congratulaba de que en enero de 1933, en Utrera (Sevilla), Cristóbal Torres y Rosario Sánchez se unían libremente sin intervención alguna de la iglesia o el Estado. La ocasión servía para conmemorar este tipo de uniones como el inicio de la extensión del amor libre en la localidad, exaltándose la importancia y el valor moral de las mismas. Estos «enlaces» acababan imitando el carácter festivo del matrimonio tradicional e imbuyéndolos en una vivencia directa del ideal, en este caso, la celebración incluía una excursión campestre que servía para fortalecer la cohesión interna del grupo. Las excursiones, organizadas generalmente por sindicatos, JJ.LL. o grupos anarquistas, era uno de esos actos que más favorecía la divulgación de las bondades de la libre unión. Sin embargo, no todas las veces las noticias eran igual de positivas. En otras ocasiones, dichas uniones eran causa de conflicto por la intolerancia social. Solidaridad Obrera señalaba en julio de 1931 que en Burriana (Castellón), la unión libre de Ramón Claus y Encarnación Casanova había causado la indignación entre «la beatería cerril de este pueblo» ${ }^{46}$ que no aceptaba la misma como una opción legítima ${ }^{47}$.

El carácter inconformista y rebelde del anarquismo hace que estas demostraciones públicas de oposición no sólo no lo amilanen, sino que no se rechaza el conflicto para provocar el enfrentamiento entre las dos morales en pugna. Tierra y Libertad publicaba la primera unión libre que tenía lugar en el pueblo manchego de Membrilla en enero de 1936: «se han unido libremente, saltando por encima de la triple autoridad religiosa, civil y paterna, rompiendo con la tradicional rutina y obedeciendo sólo a los dictados del corazón y la conciencia emancipada ${ }^{48}$. Domina la percepción de que cada unión libre suponía un éxito parcial que acercaba el triunfo final del comunismo libertario y favorecía la cosificación del amor libre, ya que suponía el inicio paulatino de la modificación de un habitus por otro. Sin embargo, prevalecería una tendencia pragmática que aceptaba y reivindicaba el matrimonio civil como opción válida, ya que a pesar de suponer la aceptación fáctica del Estado como intermediario, se acaba aceptando por su carácter

\footnotetext{
46 Solidaridad Obrera, 218, 31-07-1931, p. 6.

47 El Luchador, 93, 13-01-1933, p. 4.

48 Tierra y Libertad, 3, 24-01-1936, p. 2.
} 
subversivo contra la moral católica: $\ll_{i}$ Ved en la iglesia vuestro enemigo, el que nos ha robado la inteligencia, el pan y la libertad!» ${ }^{49}$.

El Sembrador, periódico de los cenetistas de Igualada (Barcelona), señalaba con orgullo que el matrimonio civil de Miguel Poch y María Flo en Vallbona (Barcelona) era un «exemple a imitar» ${ }^{50}$. Y La Voz del Campesino de Jerez se congratulaba del matrimonio entre José Sánchez y María Hernández en Paterna de Rivera (Cádiz) a finales de 1932 por ser de los primeros que se realizaban en la localidad sin intervención religiosa. Javier Serrano justificaba este comportamiento porque, aunque incumplía la idea de que un anarquista nunca debía aceptar la autoridad estatal, en caso de manifiesta necesidad era un mal menor. Esta realidad hizo que durante la Segunda República y en virtud del artículo 56 del Código Civil, a pesar del manifiesto anti-estatismo ácrata, los casamientos civiles entre libertarios se convirtieran en mayoritarios frente a las uniones libres, despertando no pocas críticas en muchos sectores del movimiento anarquista ${ }^{51}$ :

«Que estos casamientos civiles se hubieran hecho hace veinte años, tendrían su mérito, pero que se hagan hoy no tienen para mí ninguno. Mientras el hombre y la mujer vivan sometidos a la esclavitud económica y a la tiranía política, como quiera que se unan tienen que ser el uno víctima del otro» ${ }^{52}$.

La ruptura del orden establecido el 18 de julio de 1936 provocaría un cambio total en el status quo hasta entonces dominante, que influiría también en la práctica del amor libre. La hegemonía alcanzada por la CNT durante la guerra - especialmente en regiones como Cataluña, Valencia o Aragón - y la quiebra del Estado republicano se concretaría en un aumento exponencial de las uniones libres y en una disminución evidente de los matrimonios civiles. Ahora, en territorios como Cataluña - dominada parcialmente por la CNT-FAI a través del Comité Central de Milicias Antifascistas de Cataluña-, la legalidad republicana se convierte en legalidad revolucionaria y ahora sindicatos, comités y milicias anarquistas se erigen en los garantes de las uniones libres a través de sus dirigen-

49 El Luchador, 93, 13-01-1933, p. 3.

50 El Sembrador, 94, 06-05-1933, p. 2.

51 La Voz del Campesino, 59, 05-11-1932; La Revista Blanca, 326, 19-04-1935, p. 382; Solidaridad Obrera, 1154, 27-12-1935, p. 7; Solidaridad Obrera, 349, 02-01-1932, p. 7; Vía Libre, 12, 19-12-1936, p. 4.

52 La Voz del Campesino, 68, enero de 1933, p. 6. 
tes, que se encargan de sancionarlas. Son festejos en los que se repite el esquema tradicional de celebraciones basadas en reuniones de grupos de amigos, familiares, compañeros de trabajo y del sindicato que celebran un pequeño banquete con comida y bebida. Además, al tiempo que se producen estos casamientos se iba a extender también el empleo por parte de la prensa anarquista de un lenguaje tradicional - con términos como «desposados» o «matrimonio» - para designar las uniones libres, a pesar del riesgo evidente de que se confundieran ambos tipos de enlaces ${ }^{53}$.

Este «casarse a la libertaria», novedoso de este periodo bélico, tenía la particularidad de que los contrayentes precisamente por tratarse de una época inestable socialmente, buscan algún tipo de legitimidad que resguarde su unión. Éstas iban a acontecer, por lo general, en emplazamientos o sitios relacionados directamente con el colectivo anarquista, como fue el caso del casamiento entre José Avellana y Lola Baños que tuvo lugar en el comité revolucionario de la barriada de Gracia en septiembre de 1936 en Barcelona. Lo mismo sucedería en el caso de Gabriel Monteagudo y Teresa Serrano, en octubre de ese mismo año, pero esta vez ante el comité homónimo de Tarrasa. La ceremonia en sí se celebraba ante la presidencia del comité que, después del intercambio de las fórmulas preceptivas en las que se prometían ser fieles el uno al otro y mantener el respeto por sus ideales, el responsable de «oficiar» la unión - repitiéndose la fórmula tradicional que antes representaba el juez o el cura - les expedía un documento en el que aparecían oficialmente como casados. El mismo esquema se repite en el matrimonio de Jaime García y Ángela Pérez en Barcelona, o en el de José Sánchez e Isabel García en Badalona a finales de 1936: el secretario de la Federación Local de la CNT casaba a los novios ante dos testigos que daban fe de la unión ${ }^{54}$.

53 Solidaridad Obrera, 1154, 27-12-1935, p. 7; Solidaridad Obrera, 349, 02-01-1932, p. 7; Vía Libre, 12, 19-12-1936, p. 4. La coyuntura política y social del momento condicionaba, como indica la Teoría de Oportunidades Políticas de Tarrow, la forma en que se desarrollan ciertos elementos constitutivos del aparato estatal. Extrapolado al caso del anarquismo, las formas de acción colectiva anti-estatal fueron canalizadas hacia una actuación política revolucionaria. Se pretendía estimular la solidaridad del colectivo para dirigir el esfuerzo subversivo de forma constructiva y demostrar que la revolución no era un mito del futuro, sino una realidad del presente. Tarrow, 1997.

${ }^{54}$ En algunas celebraciones, como en el caso del matrimonio de Luís Castany y Petra Ceballos en enero de 1937 en Ribas de Freser (Gerona), el acto se cerraba con la ejecución del himno anarquista «Hijos del Pueblo». Registro Civil de Barcelona, n. ${ }^{\circ}$ 621, folio 65, tomo 49-4, 19-10-1936; Registro Civil de Badalona, n. ${ }^{\circ}$ 15, folio 16, 17-12-1936; Pluma Libre, 13, 17-01-1937, p. 8; Solidaridad Obrera, 1391, 29-09-1936, pp. 3, 10. 
De las uniones producidas en los meses posteriores a julio de 1936, uno de los más paradigmáticos fue el de Juan Freixas y Tomasa Costa. A finales de septiembre de 1936, la pareja se unía libremente en la sede del sindicato del Transporte de Barcelona, siendo «casados» por Liberto Calleja - que fue durante la guerra director de periódicos como «Solidaridad Obrera» o «CNT»-, cuyo discurso final concluía con la fórmula: «iEn nombre de la libertad, quedáis unidos!». La relevancia de esta celebración es que se trata de la primera unión matrimonial anarquista celebrada en un sindicato, de ahí que se pueda afirmar que estos casamientos nacen tan sólo dos meses después del inicio de la guerra y en el ámbito catalán. Sin embargo, no sería hasta noviembre de 1938, y dado que Juan Freixas fue destinado al frente, cuando legalizarían oficialmente su unión ante el Registro Civil de Barcelona como una medida para garantizar que Tomasa Costa, en caso de defunción de Juan, fuera reconocida como viuda. Con el final de la Guerra Civil, las nuevas autoridades franquistas iban a considerar sin validez los matrimonios civiles y uniones libres habidas durante la misma, de ahí que no fuera hasta 1950 cuando la pareja consiguiera finalmente ser reconocidos como matrimonio legal tras casarse por el rito católico en octubre de ese año ${ }^{55}$.

Sin embargo, estas medidas fueron muy criticadas por muchos sectores dentro del movimiento libertario como sería el caso de Mujeres Libres, que reprobaba que aún en periodo revolucionario se siguieran produciendo matrimonios de corte tradicional auspiciados por los sindicatos. No sólo denunciaba que se respetaban las formalidades antiguas sino que hasta se entregaban a las parejas documentos que oficializaban el matrimonio con el sello de la organización. Son uniones que Lucía Sánchez Saornil denominaría despectivamente «casamientos a la libertaria» porque mantienen, en su opinión, el engaño tradicional que antes ejercían el cura y el juez. Según testimonio de Sara Berenguer, una de las parejas que se había casado cuando ejercía como secretaria del comité revolucionario de la barriada de las Corts en Barcelona acabó solicitando su divorcio. La militante catalana no podía comprender que una pareja anarquista pidiera el divorcio. Estas situaciones demuestran que la militancia no había interiorizado realmente unos principios que abo-

55 Solidaridad Obrera, 1391, 29-09-1936, pp. 3; Registro Civil de Barcelona, n. . 353, folio 194 , tomo $69,10-11-1938$. 
gaban por que la unión se acabara tan pronto como se rompiera el afecto y la convivencia ${ }^{56}$.

Casamientos de esta índole se producen también en el frente de Aragón e influidos por las milicias antifascistas procedentes de $\mathrm{Ca}$ taluña. José Montaño y María Pérez se desposaron en Puebla de Valverde (Teruel) ante el comité de guerra de la Columna de Hierro. En esta ocasión, aparecen los tradicionales testigos que dan fe de la unión, lo que es una muestra más de que la traslación de los ritos tradicionales propios de los casamientos antiguos son integrados y adaptados a los nuevos tiempos. Por el boletín de guerra de la Columna Durruti, El Frente, conocemos que las uniones entre milicianos y milicianas son tan habituales, hasta el punto que se producen en grupo. Hasta el 8 de octubre de 1936, el récord estaba en tres casamientos en un solo día. En esa fecha se registran un total de cinco, extendiéndose después la fiesta a todo el pueblo de Pina de Ebro. En el caso de los matrimonios celebrados en el frente, revisten un carácter higiénico por la suposición de que los hombres que se casan no acudirían al contacto sexual con prostitutas disminuyendo así el riesgo a la contracción de enfermedades venéreas. Hanns-Erich Kaminski, durante su estancia en España entre septiembre de 1936 y febrero de 1937, constataría que muchos de esos matrimonios se conciertan de forma habitual ante el secretario del sindicato del ramo correspondiente. Para el periodista alemán las uniones libres son en la práctica uniones similares a las tradicionales, aunque sin la presencia del juez o el cura. Tal llegaría a ser el volumen de este tipo de casamientos que se tiene la necesidad de regularizarlos en virtud del artículo 5. ${ }^{\circ}$ del Decreto de la Generalidad de Cataluña del 2 de octubre de 1936, en el que se ordenaba la inscripción de todas las uniones realizadas hasta la fecha en el Registro Civil local con la siguiente fórmula ${ }^{57}$ :

«En virtud de lo mandado por el Juez Municipal de esta ciudad en providencia de fecha de hoy se manda transcribir el acta de matrimonio que copiada literalmente dice así:

56 «Proyecto para la creación de una fábrica de bodas en serie (Churros auténticos), Mujeres Libres, Barcelona, n. ${ }^{\circ}$ 15, 1938; Sánchez Saornil, s.d., pp. 25, 26; Ackelsberg, 1999, pp. 206, 273, 274; Nash, 1981, p. 110; Berenguer, 1984, p. 52.

57 Vida Nueva, 17, 30-10-1936, p. 1; Línea de Fuego, 33, 31-10-1936, p. 3; El Frente, 30,09-10-1936, p. 2; Kaminski, 1976, pp. 63, 64. 
Federación Local de Sindicatos únicos A.I.T.C.N.T. Badalona.

Acta de matrimonio.

Ante mi Rizal Robert, secretario de la F. Local de Sindicatos Únicos de Badalona, en la ciudad de Badalona, siendo las ............... minutos de la tarde del día de de mil novecientos treinta y en el local de la Federación Local de Sindicato Único C.N.T. sito en la calle de Francisco Layret n. ${ }^{\circ} 62$ han comparecido el camarada ................. de ................ años de edad, de profesión ................, vecino de ................., calle de ................, natural de .................y la camarada ................. de ................ años de edad, de profesión ................., vecina de ................., calle de ................, natural de ................. El primero de los comparecientes es hijo de ............... y de ................, naturales de La segunda es hija de ................. de ..............., naturales de ............... y los cuales manifiestan que teniéndose que marchar al frente ................ desean contraer Matrimonio Civil con la mayor urgencia.

Ambos han manifestado su voluntad libre de unirse en matrimonio solicitando una vez casados se inscriba esta acta en el Registro Civil de esta ciudad. - Habiendo sido testigos presenciales los camaradas $\mathrm{y}$ , vecinos de esta ciudad [...]-.

De todo lo que se extiende la presente acta firma remitiendo una copia de esta acta al Registro civil para su correspondiente transcripción $[\ldots] \gg^{58}$.

Esta disposición legal, firmada por el consejero de Economía catalán, el poumista Andrés Nin, reconocía en su artículo 1. ${ }^{\circ}$ la necesidad de convertir en sujeto jurídico a los partidos y sindicatos que formaban el Frente Antifascista de Cataluña. Ese mismo mes de octubre, para hacer frente a la situación de desamparo de aquellos que se habían unido sin sanción legal y tenían que marchar al frente, el ministro de Justicia de la República, el cenetista Juan García Oliver, promovía la legalización de las uniones de los milicianos en combate. Con esta medida se pretendía solucionar el problema generado por el fallecimiento de éstos en batalla de forma que sus esposas tuvieran derecho a la compensación eco-

${ }^{58}$ Registro Civil de Badalona, n. ${ }^{\circ}$ 16, folio 17, 14-12-1936. 
nómica que se otorgaba a las viudas de las parejas casadas legalmente. García Oliver, en una valoración de su actividad ministerial, estimaba dicha disposición como uno de los principales logros de su desempeño en el cargo, pero sin hacer referencia a lo que suponía tal decisión: acabar en el fondo con las uniones libres. Se abandonaba el radicalismo ideológico para aceptar la vinculación de la unión libre con un matrimonio civil legitimado por un Estado en el que la CNT se había vinculado con consejeros y ministros, imponiéndose así definitivamente el pragmatismo $^{59}$.

\section{Conclusiones}

La exigencia moral ácrata, junto a su carácter ascético y martirial, situaba la ideología en una esfera práctica que requería de militantes que se sacrificaran por la revolución. La mayoría asumían que esta lucha debía realizarse a nivel político e institucional para crear una sociedad sin clases ni Estado, pero pocos llegaban a asumir la necesidad de que el anarquista debía comportase éticamente según los principios que defendía en todos los ámbitos de la vida. Este carácter totalizador de la cultura ácrata se extendía especialmente al ámbito de la sexualidad y las relaciones sentimentales de pareja como elementos clave en el proceso de liberación del individuo de la sociedad y la moral dominante. El rígido moralismo ácrata centra el discurso de lo privado en la crítica del matrimonio burgués, el concepto patriarcal de familia y condena de la prostitución, contraponiendo el amor libre como la solución perfecta al problema. Pero, ¿hasta qué punto existía la conciencia común y homogénea de lo que significaba el amor libre?

La idea de la representación, adaptada a la realidad anarquista y al tema que nos ocupa, permite dividir la propaganda de las ideas del amor libre en dos realidades: por un lado, la creación de la imagen teórica y el significado del concepto y, por otro lado, su aceptación y desarrollo práctico. De este modo, se consigue reflejar la profunda dicotomía existente entre ambas esferas de la realidad tanto en su parte teórica como práctica, influida así mismo por la mentalidad imperante, la cultura heredada y la personalidad de cada individuo. Se evidencia que estos ha-

59 Diario Oficial de la Generalitat de Catalunya, 278, 04-10-1936, p. 53. 
bitus de los que hablaba Bourdieu, son extraordinariamente poderosos en las individualidades que forman el colectivo ácrata hasta el punto de condicionar la praxis de una ideología que siempre va a «sufrir» un proceso de modificación desde la propia mentalidad del individuo que la pone en práctica. El anarquismo iba a encontrarse con el obstáculo principal de conseguir extirpar unos habitus tradicionales y sustituirlos satisfactoriamente por otros nuevos. Sin embargo, sí iba a conseguir generar el espacio intelectual necesario para debatirlos, concienciar al resto del movimiento e intentar aplicarlos para, de este modo, a través de décadas de pedagogía libertaria sobre las bondades del amor libre, conseguir que muchos anarquistas se posicionaran a favor de vivir un poco más su ideal.

El presente trabajo viene a demostrar que la práctica sentimental en el anarquismo español de los años treinta era diversa y en, muchas ocasiones, contradictoria. Su heterogeneidad respondía a la propia idiosincrasia de un movimiento contrario a la fijación de la teoría en un cuerpo dogmático que encorsetara al individuo a la hora de tomar decisiones sobre su propia persona. Esta característica permitía de facto la existencia de varios modelos teóricos sobre el amor y las relaciones sexuales que pueden dividirse en dos grandes bloques. Por un lado, una relación de tipo monógamo, con ciertas concomitancias con una unión tradicional, de carácter extralegal al producirse al margen de la Iglesia y el Estado y que debía respetar los principios de igualdad, respeto mutuo y libertad. Y, por otro, la poligamia amorosa, menos difundida en España y en la que sus practicantes concebían la sexualidad, no desde un punto de vista de satisfacción personal, sino como un camino hacia la libertad individual y una forma de luchar contra el orden establecido y la moral dominante. Sin embargo, al margen de la concepción teórica, la práctica se hacía mucho más compleja y difusa.

El advenimiento de la República era una oportunidad para construir nuevos espacios de libertad y dar un paso más en el proceso de experimentación de la ideología ácrata. Si bien es cierto que durante la República surgieron casos de uniones libres, se produjo un aumento de los matrimonios civiles debido a que se consideraba el casamiento al margen de la Iglesia parcialmente revolucionario porque quebraba la moral social dominante. El amor libre tropezaba además con las reticencias de muchas mujeres de unirse sexualmente con hombres anarquistas, todavía imbuidos de cierta actitud machista hacia el sexo, por el riesgo de quedarse embarazadas o ser abandonadas. La existencia de una sociedad en la que 
la mujer tenía enormes problemas para encontrar trabajo y ganar un salario adecuado para mantener a su familia hacía que un descalabro amoroso propiciara verse abocada a la pobreza, la marginación o, incluso, la prostitución.

La permanencia de prejuicios respecto al sexo y la supeditación de la mujer al hombre eran lacras culturales que mantenían muchos militantes libertarios, a pesar de la propaganda en contra lanzada por grupos anarquistas, sindicatos y ateneos libertarios. Al mismo tiempo, dada la moral de la época de la que el anarquismo no era ajeno, cuando se debate acerca de las relaciones amoroso-sexuales éstas iban a ceñirse casi en su totalidad a relaciones heterosexuales, ya que la opción de unión sentimental homosexual no era contemplada todavía como una alternativa públicamente viable. De este modo, a pesar de que muchos militantes acababan transmitiendo de forma inconsciente comportamientos de género tradicionales, ensalzando la idea de la virilidad como virtud masculina y la sensibilidad por contra como propia de la mujer, en el fondo, no puede señalarse que los hombres ácratas se vieran impelidos a una práctica más relacionada con la camaradería amoroso-sexual que las mujeres, ya que ambos buscaban relaciones monógamas libres. La persistencia de esa tradicional libertad del hombre para tener una vida sexual menos opresiva era lo que se reflejaba en aquellos hombres que, aunque autodenominándose anarquistas, no buscaban una transformación real de las estructuras mentales, sino que todo siguiera (al menos en cuanto a las relaciones y al sexo se refiere) igual.

Con el inicio de la Guerra Civil y el consiguiente cambio en las estructuras de poder, especialmente en la región catalana, se produce un aumento exponencial de las uniones libres y el nacimiento de un nuevo tipo de unión que podría ser definida como «casamiento sindical». Dicha unión refleja toda la formalidad propia de un matrimonio civil pero, en lugar de realizarse en una iglesia o ante el juez, tenía lugar en la sede de algún sindicato o comité revolucionario que bendecía y daba formalidad a la unión. La posición de poder alcanzada por la CNT, había generado nuevos habitus y nuevas formas de sociabilidad amorosa que consolidaban al sindicato como el centro de la nueva estructura social. El Matrimonio civil o el casamiento sindical suponían en la práctica una ruptura con el status quo establecido y demostraba un manifiesto pragmatismo del anarquismo a la hora de llevarlo a la práctica, aunque, en el fondo, se desvirtuaba la imagen teórica del amor libre tal y como había sido concebido por los propagandistas ácratas. 


\section{Fuentes}

Biblioteca del Ateneu Enciclopèdic Popular, Barcelona.

Biblioteca Virtual de Prensa Histórica, Ministerio de Educación, Cultura y Deporte.

Bibliotecas Municipales de la Diputació de Barcelona.

Centro de Documentación para la difusión de la Memoria Histórica Antiautoritaria y Libertaria (CEDALL), Barcelona

Centro de Estudios de Castilla la Mancha (UCLM), Ciudad Real.

CRAI Biblioteca del Pabellón de la República, Barcelona.

Hemeroteca de la Biblioteca Nacional de España, Madrid.

Hemeroteca Municipal de Valencia

International Institute of Social History (IISH), Amsterdam.

Registro Civil de Badalona

Registro Civil de Barcelona

\section{Bibliografía}

ACKELSBERG, Martha, Mujeres Libres. El anarquismo y la lucha por la emancipación de las mujeres, Virus editorial, Barcelona, 1999.

Álvarez Junco, José, La ideología política del anarquismo español (18681910), Siglo Veintiuno de España, Madrid, 1991.

Álvarez Lacruz, Alfredo, El amor: de Platón a hoy, Palabra, Madrid, 2006.

ANDRÉS GRANEL, Helena, «Anarquismo y sexualidad», Germinal: revista de estudios libertarios, n. ${ }^{\circ}$ 5, 2008, pp. 65-84.

AviLÉs FARRÉ, Juan, «Fuentes literarias e historia social», Studia histórica. Historia Contemporánea, n. ${ }^{\circ}$ 6-7, 1988-1989, pp. 67-78.

BajATIERra, Mauro, Como palomas sin nido: comedia de tesis defendiendo el derecho íntegro de la mujer, Biblioteca Plus-Ultra, Madrid, 1934.

BERENGUER, Sara, Entre el sol y la tormenta. Treinta y dos meses de guerra (1936-1939), Seuba, Barcelona, 1984.

Bourdieu, Pierre, El sentido práctico, Siglo XXI, Buenos Aires, 2007.

Bourdieu, Pierre, El sentido social del gusto: elementos para una sociología de la cultura, Siglo XXI, Buenos Aires, 2010.

Caro Crespo, Francisco, El último baluarte, Publicaciones La Revista Blanca, Barcelona, 1927.

ChARTIER, Roger, La historia o la lectura del tiempo, Gedisa Editorial, Barcelona, 2007.

CHozA, Jacinto, Historia de los sentidos, Ed. Thémata, Sevilla, 2011. 
Cleminson, Richard, Anarquismo y sexualidad en España (1900-1939), Servicio de Publicaciones Universidad de Cádiz, Cádiz, 2008.

CORONA BERKIN, Sarah, RodríGuez Morales, Zeyda, «El amor como vínculo social, discurso e historia. Aproximaciones bibliográficas», Espiral: Estudios sobre Estado y Sociedad, vol. 6, n. ${ }^{\circ}$ 17, 2000, pp. 49-70.

CoRTI, Annalisa, «"La Revista Blanca”(1923-1936)», Estudios de historia social, n. ${ }^{\circ}$ 40-41, 1987, pp. 103-264.

DíEz, Xavier, Utopía sexual a la premsa anarquista de Catalunya: la revista «Ética-Iniciales» (1927-1937), Pagès editors, Barcelona, 2001.

DíEz, Xavier, «"Amaos y no os multipliquéis”. El discurso ético-sexual del anarquismo individualista en Cataluña (1927-1937)», en Spagna contemporanea, n. ${ }^{\circ} 21,2002$, pp. 99-214.

DíEz, Xavier, El Anarquismo individualista en España (1923-1938), Virus editorial, Barcelona, 2007.

ESPIGADO ToCiNO, Gloria, «Las mujeres en el anarquismo español», Ayer, n. ${ }^{\circ}$ 45, 2002, pp. 39-72.

ESPIGADO TOCINO, Gloria, «Amor y deseo en los medios anarquistas. «La Victoria» de Federica Montseny. Escritos “en defensa de Clara”», en EsPIGADO Tocino, Gloria, de la Pascua SÁnchez, María José, García-Doncel HerNÁNDEZ, María del Rosario, Mujer y deseo: representaciones y prácticas de vida, Servicio de Publicaciones de la Universidad de Cádiz, Cádiz, 2004, pp. 467-484.

Fontanillas, Antonia, Torres, Sonya, Lola Iturbe. Vida e ideal de una luchadora anarquista, Virus editorial, Barcelona, 2006.

Fuchs, Eduard, Historia ilustrada de la moral sexual: 3. La época burguesa, Alianza Editorial, Madrid, 1996.

Gallardo, Mariano, El sexo, la prostitución, el amor, Ediciones Universo, Toulouse, s.d.

GARCíA-MARoto, María Ángeles, La mujer en la prensa anarquista, Fundación Anselmo Lorenzo, Madrid, 1996.

Goode, William, «The theoretical importance of love», American Sociological Review, n. ${ }^{\circ} 24,1959$, pp. 38-47.

ÍñIGUEZ, Miguel, Esbozo de una enciclopedia histórica del anarquismo español, Fundación de Estudios Libertarios Anselmo Lorenzo, Madrid, 2001.

KAmINSKI, Hanns-Erich, Los de Barcelona, Ediciones del Cotal S.A., Barcelona, 1976.

LóPEz CAMPILlo, Evelyne, «Vanguardia burguesa y cultura anarquista en la Revista Blanca (1923-1936)», en HofmanN, Bert, JoAn I Tous, Pere, TiETzE, Manfred (Eds.), El anarquismo español y sus tradiciones culturales, Vervuert-Iberoamericana, Frankfurt am Main, 1995, pp. 237-242.

Lora Medina, Alejandro, «Consideraciones sobre el homosexualismo en el anarquismo español de los años 30», en CASAS SÁNCHEZ, José Luis, Du- 
RÁN AlCalÁ, Francisco, Republicanismo en España. Cultura, política e ideologías, Actas del VII Congreso sobre el republicanismo celebrado en Priego de Córdoba el 12, 13 y 14 de diciembre de 2013, Patronato Municipal Niceto Alcalá-Zamora y la Diputación Provincial de Córdoba, Córdoba, 2015, pp. 207-224.

Lora MEDina, Alejandro, «La visión ontológica de la mujer y el hombre en el anarquismo de los años treinta: identidad y género a debate», Brocar, n. ${ }^{\circ} 41$ (2017), pp. 153-185.

Lora Medina, Alejandro, «La vivencia del ideal anarquista en la España de los años treinta», Hispania Nova, n. ${ }^{\circ} 16$ (2018), pp. 181-203.

NASH, Mary, Mujer y movimiento obrero en España, 1931-1939, Editorial Fontamara, Barcelona, 1981.

NASH, Mary, «La reforma sexual en el anarquismo español», en HofMANN, Bert, JoAn I Tous, Pere, Tietze, Manfred (Eds.), El anarquismo español y sus tradiciones culturales, Vervuert-Iberoamericana, Frankfurt am Main, 1995, pp. 281-296.

NASH, Mary, Rojas. Las mujeres republicanas en la Guerra Civil, Taurus Alfaguara, Madrid, 1999.

NAVArro Navarro, Francisco Javier, El paraíso de la razón: la revista «Estudios» (1928-1937) y el mundo cultural anarquista, Servicio de Publicaciones Generalitat Valenciana, Valencia, 1997.

Pestaña, Ángel, ¡Huyamos!, Publicaciones La Revista Blanca, Barcelona, 1935.

Rodríguez SalazAr, Tania, El amor en las ciencias sociales. Cuatro visiones teóricas, Culturales, vol. 15, 2012, pp. 155-180.

SÁNChEZ SAORNIL, Lucía, Horas de revolución, Publicaciones Mujeres Libres, Barcelona, s.d.

SANFELIU, Luz, «Educando y viviendo en la "libertad sexual". "Mujeres Libres" y Lucía Sánchez Saornil», en OSBORnE, Raquel, Mujeres bajo sospecha (memoria y sexualidad, 1930-1980), Fundamentos, Madrid, 2012, pp. 331346.

SELLÉS, Juan Fernando, «El amor: ¿pasión, sentimiento, estado? Revisión de relevantes tesis del s. XX», Endoxa. Series filosóficas, n. ${ }^{\circ} 32,2013$, pp. 107131.

Stone, Lawrence., Familia, sexo y matrimonio en Inglaterra, Fondo de Cultura Económica, México, 1990.

TARrow, Sidney, El poder en movimiento. Los movimientos sociales, la acción colectiva y la política, Alianza, Madrid, 1997. 


\section{Datos del autor}

Cursó la licenciatura de Historia y el máster de «Estudios Históricos Comparados" en la Universidad de Sevilla entre 2005-2012. Por su expediente académico le fue concedida una beca PIF (Personal Investigador en Formación) por la universidad para la realización de una tesis doctoral dentro del Departamento de Historia Contemporánea, con título: «El poder de las ideas: percepciones y representaciones en el anarquismo español de los años treinta». Durante ese periodo de cuatro años asistió a varios congresos, realizó varias publicaciones relacionadas con mi investigación y estancias de investigación en Barcelona (Ateneu Enciclopèdic Popular y Biblioteca del Pabellón de la República) y Ámsterdam (International Institute of Social History). Finalmente, en diciembre de 2016 obtuvo la calificación de sobresaliente cum laude por mi tesis doctoral. 